\title{
ARTIFICIAL NEURAL NETWORKS FOR PREDICTION OF PHYSIOLOGICAL AND PRODUCTIVE VARIABLES OF BROILERS
}

\author{
Lucas H. P. Abreu ${ }^{*}$, Tadayuki Yanagi Junior ${ }^{1}$, Marcelo Bahuti ${ }^{1}$, Yamid F. Hernández-Julio² \\ Patrícia F. P. Ferraz ${ }^{1}$
}

${ }^{1 *}$ Corresponding author. Federal University of Lavras/ Lavras - MG, Brazil.

E-mail: lucas.abreu@ufla.br | ORCID ID: https://orcid.org/0000-0002-5295-0177

\begin{abstract}
KEYWORDS
poultry, thermal stress, artificial intelligence.
\end{abstract}

\begin{abstract}
Due to a number of factors involving the thermal environment of a broiler cutting installation and its interaction with the physiological and productive responses of birds, artificial intelligence has been shown to be an interesting methodology to assist in the decision-making process. For this reason, the main aim of this work was to develop an artificial neural network (ANN) to predict feed conversion (FC), water consumption $\left(\mathrm{C}_{\text {water }}\right)$, and cloacal temperature $\left(\mathrm{t}_{\mathrm{clo}}\right)$ of broilers submitted to different air dry-bulb temperatures $\left(24,27,30\right.$, and $\left.33^{\circ} \mathrm{C}\right)$ and durations $(1,2,3$, and 4 days) of thermal stress in the second week of the production cycle. Relative humidity and wind speed were fixed at $60 \%$ and $0.2 \mathrm{~ms}^{-1}$, respectively. The experimental data were used for the development of an ANN with supervised training using the Levenberg-Marquardt backpropagation algorithm. The ANN consisted of three input layers one hidden, and three output with sigmoidal tangent transfer functions with values between -1 and 1 . The developed ANN has adequate predictive capacity, with coefficients of determination $\left(\mathrm{R}^{2}\right)$ for $\mathrm{t}_{\text {clo, }} \mathrm{FC}$, and $\mathrm{C}_{\text {water }}$ of $0.79,0.87$, and 0.97 , respectively. In this way, the proposed ANN can be used as a support for decision-making to trigger poultry heating systems for broiler breeding.
\end{abstract}

\section{INTRODUCTION}

In the current poultry scenario, changes in management techniques are indispensable. Therefore, the use of intelligent systems for decision-making is necessary to obtain a maximum index of market performance and competitiveness (Pandorfi et al., 2012), in addition to mitigating or even eliminating the harmful effects of a thermal environment unsuitable for the physiological demands of birds (Nascimento et al., 2014).

Several studies have verified only the influence of different thermal stress intensities, without varying the duration of the thermal stress (Al-Zghoul et al., 2015; Cândido et al., 2016: Zhang et al., 2016). However, analyzing the intensity and duration together makes it possible to investigate possible occurrences of adaptation of the bird to the stressful environment, depending on the exposure time, or to verify how stressor intensity can aggravate productivity losses due to longer or shorter exposure times. Thus, the control of environmental variables becomes essential for the process of rearing broilers (Cassuce et al., 2013; Mirzaee-Ghaleh et al., 2015).

The evaluation of the thermal comfort of birds can be measured by cloacal temperature, which is altered when the bird is subjected to thermal stress (Yanagi Junior et al., 2012; Mayes et al., 2014). Also, discomfort influences water consumption (Lopes et al., 2015), feed intake, and weight gain, affecting feed conversion (Boiago et al., 2013).

Therefore, the importance of monitoring the thermal stress of broilers and the influence on behavioral parameters, physiological responses, and productive performance has been verified. Thus, through information generated by intelligent systems, the producer will be able to control his business more appropriately (Pandorfi et al., 2012; Ferraz et al., 2014).

Among these systems, we can include artificial neural networks (ANNs), which consist of computational models formed by simple processing units based on the structure of the human brain, thus called artificial neurons (Binoti et al., 2013). These units allow the system to

\footnotetext{
${ }^{1}$ Federal University of Lavras/ Lavras - MG, Brazil.

${ }^{2}$ Universidad del Sinú Elías Bechara Zainúm/ Montería, Colômbia.

Area Editor: Héliton Pandorfi

Received in: 2-8-2019

Accepted in: 11-01-2019
}

Engenharia Agrícola, Jaboticabal, v.40, n.1, p.1-9, jan./feb. 2020 
simulate behaviors, such as learning, association ability, generalization, and abstraction, which are based on the logic of parameters (Ferreira et al., 2011).

The applicability of ANNs is associated with situations where input and output information are interconnected by a nonlinear relationship of dependent and independent variables. Thus, ANNs can be used for predicting and representing parameters not quantified from data evaluated by behavior patterns, thus allowing the development of techniques for solving complex problems (Pandorfi et al., 2011; Matin et al., 2012).

In this sense, mathematical modeling through ANNs is a critical methodology for the analysis of complex systems, such as the prediction of the thermal comfort of broilers. ANNs forecast different answers that quantify animal comfort, such as productive and physiological responses in the same network. Thus, there exist several studies that implement ANNs applied to predicting and managing environment and responses in animal production (Borges et al., 2018; Ribeiro et al., 2019; Santos et al., 2016).

Therefore, the main objective of this study was to develop an ANN to predict the cloacal temperature, water consumption, and feed conversion of broilers subjected to different intensities and durations of thermal stress during the second week of the production cycle.

\section{MATERIAL AND METHODS}

The research was developed in four air-conditioned wind tunnels $(0.8 \times 5.0 \mathrm{~m})$ installed in an animal ambiance laboratory. All procedures performed during this experiment were approved by the Ethics Committee for the Use of Animals (CEUA) of the Federal University of Lavras (UFLA), Minas Gerais, protocol $N^{\circ} 008 / 12$. The airconditioned wind tunnels were constructed of steel plates and PVC pipes; each tunnel was equipped with two electric heaters and two humidifiers operating in two stages of the drive.

Ventilation inside each tunnel was performed by employing an exhaust with a diameter of $40 \mathrm{~cm}$, and the speed adjusted using a potentiometer. Inside the tunnels, cages of $0.24 \mathrm{~m}^{2}(0.40 \times 0.60 \mathrm{~m})$ were allocated, which were divided into three equal parts and equipped with independent feeders and drinking fountains in each repetition. To control the temperature inside the room, two air conditioning systems with 18,000 BTUs of power were used.

The control of the thermal environment within the air-conditioned wind tunnels was carried out by the combination of a data logger (CR1000, Campbell Scientific), a relay controller (SDM-CD16AC, Campbell Scientific), a channel multiplexer (AM16/32B, Campbell Scientific), and air dry-bulb temperature sensors $\left(\mathrm{t}_{\mathrm{db}}\right)$ and relative air humidity $(\mathrm{RH})(\mathrm{HMP} 45 \mathrm{c}$, Vaisala, accuracy \pm $0.3^{\circ} \mathrm{C}$ for $\mathrm{t}_{\mathrm{db}}$ and $\pm 2 \%$ for $\left.\mathrm{RH}\right)$.

During the entire experimental period, Cobb $500^{\circledR}$ males and females from the same hatchery were used, where they were vaccinated against the avian diseases Marek's, Gumboro, and avian pox. The birds arrived at the experiment shortly after birth and remained until they had completed twenty-two days of life. During this period, water and ad libitum feed was supplied to birds to meet their nutritional requirements according to Rostagno et al. (2011). The feed used was the same for all chicks throughout the experimental period, with no variation in its formulation.

The experiment was carried out in four stages, in order to evaluate sixty birds in each stage, totaling two hundred and forty animals. Thus, in each distribution of the cage, five birds were allocated, characterizing fifteen birds per air-conditioned wind tunnel in the first week of life. However, to maintain the ideal density of comfort, in the second and third week of life, four and three birds were kept, respectively, according to the Cobb manual (2013), because the high density harmfully affects physiological parameters (Castilho et al., 2015). Hygienic maintenance of the breeding environment was carried out daily to avoid the formation of gases and to provide a pleasant environment for the development of broilers (Sousa et al., 2016).

The experiment was carried out for twenty-one days, in which the birds were submitted to thermal challenges only in the second week of life-from the eighth day of life. During the first and third weeks of life, temperatures were maintained in the thermoneutrality zone, with air dry-bulb temperatures $\left(\mathrm{t}_{\mathrm{db}}\right)$ of $33^{\circ} \mathrm{C}$ and $27^{\circ} \mathrm{C}$, respectively (Cassuce et al., 2013; Ferraz et al., 2018). In the second week, a difference between treatments was established by the intensity and duration of thermal stress. The stress intensities were 24,27 , and $33^{\circ} \mathrm{C}$ for each stage, in addition to $30^{\circ} \mathrm{C}$ for $t_{\mathrm{db}}$, which was considered as comfort for the second week of life (Cassuce et al., 2013; Ferraz et al., 2017).

Thermal stress was applied at four levels of duration $(1,2,3$, and 4 days) in the first four days that make up the second week (8th, 9th, 10th, and 11th days of life); shortly after this period, the temperatures returned to the thermal comfort zone $\left(30^{\circ} \mathrm{C}\right)$. The experimental stage submitted to a temperature of $30^{\circ} \mathrm{C}$ was considered the control (comfort), and the others were maintained in order to provide thermal challenges both by low $\left(24^{\circ} \mathrm{C}\right.$ and $\left.27^{\circ} \mathrm{C}\right)$ and high $\left(33^{\circ} \mathrm{C}\right)$ temperatures (Curtis, 1983; Cassuce et al., 2013).

The luminosity was fixed inside each tunnel with the aid of an analog dimmer and measured using a lux meter (LDR-380, accuracy $\pm 3 \%$ ). The established values were 25, 10, and 5 lux, for the first, second, and third week, respectively (Cobb, 2013), to provide the maximum efficiency in development that adequate lighting can generate on broilers (Lima et al., 2014). In turn, relative air humidity $(\mathrm{RH})$ was set at $60 \%$ and airspeed at $0.2 \pm 0,1 \mathrm{~m} \mathrm{~s}^{-1}$.

Cloacal temperature $\left(\mathrm{t}_{\mathrm{clo}}\right)$ was measured daily using a digital thermometer $\left( \pm 0.01{ }^{\circ} \mathrm{C}\right.$ accuracy) in a bird by distribution of the cage, totaling twelve birds per day or forty-eight in each of the four stages.

The experiment was conducted by adopting a completely randomized design (CRD) with three replicates in a factorial scheme $(4 \times 4)$, four $\mathrm{t}_{\mathrm{db}}$ in the second week of birdlife $\left(24,27,30\right.$, and $\left.33^{\circ} \mathrm{C}\right)$, and four durations of thermal stress (1, 2, 3, 4, and 5 days). 
After the experiment, a database containing the primary information of $\mathrm{t}_{\mathrm{db}}$, duration of stress (DS), days after stress (DAS), cloacal temperature $\left(\mathrm{t}_{\mathrm{clo}}\right)$, feed conversion (FC), and water consumption $\left(\mathrm{C}_{\text {water }}\right)$ was generated.

For the preparation of the ANN, the data set consisted of three input variables: $\mathrm{t}_{\mathrm{db}}\left(24,27,30\right.$, and $\left.33^{\circ} \mathrm{C}\right)$, DS (1, 2, 3, 4 days), and DAS ( $0,1,2,3,4$ and 5 days). The $\mathrm{t}_{\mathrm{clo}}\left({ }^{\circ} \mathrm{C}\right), \mathrm{FC}\left(\mathrm{g} \mathrm{g}^{-1}\right)$ and $\mathrm{C}_{\text {water }}\left(\mathrm{mL}\right.$ day $\left.^{-1}\right)$ were used as output variables. To train, validate, and test ANN-based models, the total dataset formed by 360 data pairs was used. The data were randomly divided using the random sampling function, and $70 \%$ ( 252 data pairs) of the data were used for training, $15 \%$ (54 data pairs) for validation, and 15\% (54 data pairs) for testing. These percentages for the subsets were chosen because they are those most commonly used for mathematical modeling (Brown-Brandl et al., 2005; Hernández-Julio et al., 2014). Thus, 3000 ANN-based models were developed (modifying the number of neurons in the hidden layer from 1 to 300 with 10 replications each) with the objective of predicting the three output variables $\left(\mathrm{t}_{\mathrm{clo}}, \mathrm{FC}\right.$, and $\mathrm{C}_{\text {water }}$ ), and the architecture that presented the highest correlation coefficient $\left(\mathrm{R}^{2}\right)$ and the lowest mean square error (MSE) was selected.

According to Kiran \& Rajput (2011), the formation layer is transmitted to the ANN model with the aid of a set known as data patterns, causing the network to continually "learn," adapting its weights and deviations through an activation function.

Activation functions can be sigmoid, tangentsigmoid, linear, or other types. Thus, the network is formed until the error is reduced enough to provide an accurate output to the input dataset. Model parameters include the number of hidden layers, transfer functions in each hidden layer, the number of neurons in the hidden layer, the learning rate, the moment rate, and the weights of neurons.

To develop the ANN-based models, Matlab ${ }^{\circledR}$ software, version 7.13.0.564 (R2011b), was used with the application of the neural adjustment tool (Mathworks, 2013). These models were trained using $70 \%$ of randomly divided experimental data, with different numbers of hidden neurons (from 1 to 20 , ranging from 1 to 1 ; from 25 to 200 , ranging from 5 to 5 ; and from 210 to 300 , varying from 10 to 10) for the test.
In this study, of all trained network architectures (3000) using the mentioned methodology, the tested architecture that presented the best performance for prediction of $\mathrm{t}_{\mathrm{clo}}, \mathrm{FC}$, and $\mathrm{C}_{\text {water }}$ was the multi-layer network (multi-layer perceptron; MLP) with 50 neurons in the hidden layer. This MLP architecture has been widely used for the development of ANN (Rocha Neto et al., 2015; Rigo Júnior et al., 2016; Borges et al., 2017; Felix et al., 2017).

Three feedforward layers (input, hidden layer, and output layer) and supervised training were employed with the Levenberg-Marquardt backpropagation training algorithm, which is considered the fastest method for networking (Barbosa et al., 2005). MSE was used for the performance function of the model, in which, for the output of the neuron, the sigmoidal tangent activation function was selected (Ferraz et al., 2014; Oliveira et al., 2015).

Initial network parameters were configured as follows: hidden layer (1, default value), number of times $(1000)$, error tolerance $(<0.099)$, learning rate $(0.7)$, and time rate $\left(1 \times 10^{-3}\right)$ (Hernández-Julio et al., 2014). These values, as well as neuron weights, were used as the standard configuration by the software for network training. The software optimized these values automatically. This model was developed to allow the user to train and test ANN independently. In turn, for the significance analysis of the ANN coefficients, $f-$ and $t$-tests $(p<0.05)$ were used.

\section{RESULTS AND DISCUSSION}

For the output variables cloacal temperature $\left(\mathrm{t}_{\mathrm{clo}}\right)$, feed conversion (FC), and water consumption $\left(\mathrm{C}_{\text {water }}\right)$, the ANN architectures with the best performance were chosen using the criterion of the lowest mean square error (MSE) of prediction. The MSE values in the training, validation, and testing processes were 59.16, 102.27, and 67.23, respectively. The variables chosen contributed to the learning of the network, increasing accuracy in pattern recognition (Pandorfi et al., 2011).

Adjustment of the values of the errors of the desired output versus predicted output was carried out using the Levenberg-Marquardt backpropagation algorithm (Hernández-Julio et al., 2014), in which the system made changes in the values of synaptic weights and bias values until it reached the least error. Table 1 lists synaptic and bias weights resulting from the ANN training process that achieved the best performance. 
TABLE 1. Bias and synaptic weights of input and output variables.

\begin{tabular}{|c|c|c|c|c|c|c|c|c|c|c|}
\hline & \multicolumn{4}{|c|}{ Synaptic input weights } & \multicolumn{6}{|c|}{ Synaptic output weights } \\
\hline $\begin{array}{c}\text { Number of } \\
\text { neurons }\end{array}$ & Bias & $\mathbf{t}_{\mathbf{d b}}$ & DS & DAS & telo & Bias & FC & Bias & $\mathbf{C}_{\text {water }}$ & Bias \\
\hline 1 & 5.6730 & -3.7309 & -2.1988 & -2.5360 & -0.8105 & & -1.0462 & & 0.5961 & \\
\hline 2 & 5.4965 & -1.6594 & -2.9090 & -2.6028 & -0.0417 & & 0.6430 & & -0.2194 & \\
\hline 3 & 4.5551 & -4.8295 & -1.1604 & 3.2698 & 0.5774 & & -0.3427 & & 0.3309 & \\
\hline 4 & 4.2253 & -3.7410 & -3.2180 & 1.5039 & 0.2993 & & -0.0691 & & 0.6132 & \\
\hline 5 & 3.7633 & -1.5908 & -5.6054 & 2.0938 & 0.1191 & & 0.7127 & & -0.6062 & \\
\hline 6 & 3.7993 & -5.1288 & -0.8997 & -0.9806 & 0.0360 & & 0.1020 & & 0.7392 & \\
\hline 7 & 3.9382 & -4.2414 & -2.7975 & 0.8227 & -0.1431 & & 0.4602 & & -0.9695 & \\
\hline 8 & -3.7455 & 3.2583 & -3.0143 & -1.4687 & -0.3335 & & 0.1747 & & 0.0806 & \\
\hline 9 & 3.8952 & -3.9638 & -2.6769 & -1.4269 & 0.2714 & & 0.8014 & & 0.0097 & \\
\hline 10 & -2.4731 & 0.8126 & 5.4852 & -0.7459 & 0.1950 & & 0.5199 & & -0.4965 & \\
\hline 11 & 3.4339 & -1.5757 & -4.5601 & -0.7468 & 0.4251 & & -0.0822 & & -0.0410 & \\
\hline 12 & 2.9459 & -4.4153 & 0.8536 & 2.9175 & -0.9589 & & 0.7146 & & -0.1023 & \\
\hline 13 & -2.8741 & 0.0841 & -0.3531 & 4.8561 & 0.3627 & & -0.2947 & & 0.2444 & \\
\hline 14 & -2.4693 & 3.0516 & -4.2634 & 0.3784 & -0.1241 & & -0.4582 & & -0.0999 & \\
\hline 15 & 3.4082 & -3.9547 & 1.5403 & -1.2257 & 0.0288 & & 0.3433 & & 0.2909 & \\
\hline 16 & -1.9316 & 5.2635 & -0.7620 & 0.9752 & 0.5126 & & 0.1848 & & -0.0303 & \\
\hline 17 & 1.2329 & -2.2100 & 1.3950 & -2.8426 & -0.2358 & & 0.4321 & & -1.1778 & \\
\hline 18 & 2.1046 & -2.7346 & 1.7043 & -4.0373 & -0.0693 & & -0.3800 & & 0.7716 & \\
\hline 19 & -2.0332 & 4.0696 & 3.2312 & 4.2627 & -0.9403 & & 0.1424 & & 0.0399 & \\
\hline 20 & -3.3880 & 3.3955 & -1.1837 & 3.3351 & -0.6707 & & -0.0018 & & 0.2229 & \\
\hline 21 & -0.1774 & -1.9272 & 3.2974 & 2.3974 & -0.6174 & & -0.1925 & & -0.2343 & \\
\hline 22 & -0.1527 & -4.3510 & -3.1714 & 0.8211 & 0.2560 & & -0.5563 & & 0.0761 & \\
\hline 23 & -0.5192 & -0.7998 & -2.2317 & -2.5793 & -0.9796 & & -0.5854 & & -0.0632 & \\
\hline 24 & -0.6838 & 4.0195 & -0.0300 & 4.0795 & -0.2690 & & 0.2154 & & -0.3345 & \\
\hline 25 & 0.2941 & 3.8122 & 3.5383 & -2.2838 & 1.1548 & -19518 & -1.1709 & -11428 & 0.2044 & -10346 \\
\hline 26 & 0.1135 & 4.6109 & 1.7382 & -4.5512 & -0.1423 & ס & 0.5313 & $-1.1+20$ & -0.0620 & -1.0070 \\
\hline 27 & -0.6931 & 4.1909 & 1.9806 & 4.1861 & 0.6677 & & -0.0362 & & 0.4297 & \\
\hline 28 & -0.5459 & -3.3901 & 3.1203 & 0.2114 & -0.4230 & & 0.8781 & & -0.2626 & \\
\hline 29 & -1.4810 & -3.9807 & -4.5295 & 2.5876 & 1.1113 & & -0.9750 & & 0.2020 & \\
\hline 30 & -0.9797 & 3.0255 & -3.5221 & -3.9337 & -0.2520 & & 0.1789 & & -0.2063 & \\
\hline 31 & -1.3851 & -4.7913 & 2.3962 & -1.9010 & 0.7647 & & -1.2764 & & 0.2495 & \\
\hline 32 & -2.3812 & -1.3094 & 3.5509 & 2.1522 & 0.0825 & & -0.6756 & & 0.1143 & \\
\hline 33 & 2.5705 & 3.6264 & 3.3295 & 1.4181 & -1.0652 & & 0.0338 & & -0.0028 & \\
\hline 34 & 1.4169 & 3.9074 & 3.4495 & 0.8445 & 0.5382 & & -0.4481 & & 0.4072 & \\
\hline 35 & -2.2387 & -4.8972 & 1.3467 & 0.4737 & 0.1076 & & -0.4438 & & -0.1736 & \\
\hline 36 & -2.3037 & -1.5509 & 5.0220 & 0.3295 & 0.5899 & & -0.0982 & & 0.2742 & \\
\hline 37 & -3.5870 & -2.2083 & 3.8040 & 2.1091 & -0.5302 & & 1.1806 & & -0.6557 & \\
\hline 38 & 2.4058 & 3.2096 & -0.6839 & -3.0771 & -0.2512 & & 0.3810 & & 0.0444 & \\
\hline 39 & -2.7776 & -2.8914 & -1.7215 & 1.9028 & -0.3326 & & -0.2601 & & -0.2765 & \\
\hline 40 & -1.2673 & -5.8171 & -0.0245 & -2.2488 & -0.0350 & & -0.0270 & & 0.0273 & \\
\hline 41 & 5.3834 & 0.3080 & -1.4606 & 4.3778 & -0.4368 & & -0.5450 & & 0.5777 & \\
\hline 42 & 2.3525 & 2.0842 & 3.2726 & 4.9933 & -0.5924 & & -0.2983 & & -0.1340 & \\
\hline 43 & 4.3052 & 2.5841 & 2.6182 & 4.2024 & -0.2405 & & 0.9707 & & 0.0420 & \\
\hline 44 & -4.1299 & -4.3737 & -1.7779 & 1.4595 & -0.7133 & & 1.4519 & & 0.0956 & \\
\hline 45 & 5.5556 & 0.3355 & -0.4018 & 4.4813 & 1.7529 & & 0.8221 & & -0.2202 & \\
\hline 46 & -5.6530 & -3.7297 & 1.2921 & 3.8807 & 0.4996 & & -0.3991 & & 0.8200 & \\
\hline 47 & 4.2032 & 2.4936 & -2.0691 & 6.1808 & 0.2713 & & -0.1002 & & 0.1937 & \\
\hline 48 & -5.4270 & -2.8866 & 0.2158 & 4.0836 & -0.3463 & & -0.2538 & & -0.7294 & \\
\hline 49 & 4.4499 & 5.5281 & -1.7889 & -0.6415 & 0.2831 & & -0.3974 & & -0.4044 & \\
\hline 50 & 5.3942 & 2.5977 & 3.8161 & 4.0788 & 0.8404 & & -0.7622 & & 0.0342 & \\
\hline
\end{tabular}

Legend: $\mathrm{t}_{\mathrm{db}}$ : air dry-bulb temperature; DS: duration of stress; DAS: days after stress; $\mathrm{t}_{\mathrm{clo}}$ : cloacal temperature; $\mathrm{FC}$ : feed conversion; and $\mathrm{C}_{\mathrm{water}}$ : water consumption. 
The model with the lowest values of $\operatorname{MSE}$ (59.16, 102.27, and 67.23) in the training, validation, and test data was obtained with a hidden layer consisting of 50 neurons; the highest values of MSE among all the tested architectures were 145.54, 1,935.04, and 2,140.02 for the training, validation, and test data, respectively. The number of neurons in the hidden layer for the architecture with the highest values of MSE was 230 and it obtained an $\mathrm{R}^{2}$ of 0.875 . Figure 1 illustrates that the lowest value was obtained on the tenth cycle. The maximum number of seasons was 15 , and the final momentum rate was 0.1 . The function used to stop training was "minimum gradient reached." The output layer was composed of three neurons ( $\mathrm{t}_{\mathrm{clo}}, \mathrm{FC}$, and $\left.\mathrm{C}_{\mathrm{water}}\right)$.

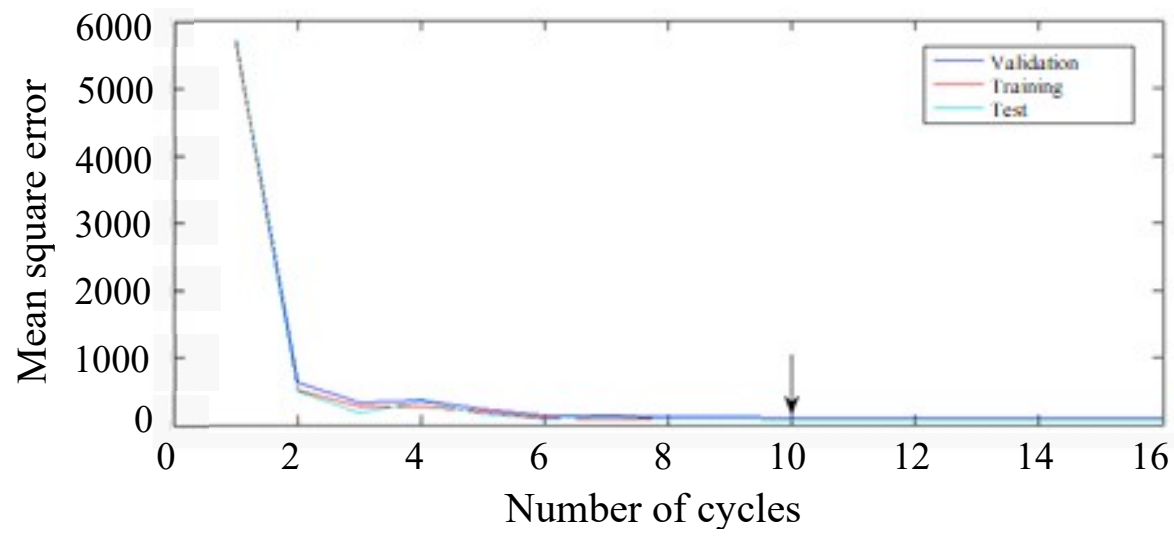

FIGURE 1. ANN training curve for the renewal of synaptic weights.

As the number of neurons in the hidden layer increases, performance improves and reaches satisfactory levels; however, if the number of neurons in the hidden layer is excessive, performance can be compromised, because many weights and the bias of neurons could have values equal to zero and would increase the processing of output value calculations (spatial and temporal complexity). In this case, the methodology proposed by Ferraz et al. (2014) recommends using the model with the best performance, using the highest coefficient of determination $\left(\mathrm{R}^{2}\right)$ and the lowest MSE. Thus, these values were obtained with values of intermediate neurons.

The efficiency of the model presented in this study corroborates the studies conducted by Klassen et al. (2009), who used ANN to model the cooling process of chicken carcasses in immersion tanks, in which artificial neural networks were adequate for the modeling of the researched system.

In this work, the simulation of the model was performed according to the combination of the input variables $t_{d b}$, DS, and DAS, to predict $t_{c l o}, F C$, and $C_{w a t e r}$. The simulated values were compared with the experimental data obtained in the air-conditioned wind tunnels, and the means, medians, and minimum and maximum values for mean deviation, standard deviation, and percentage error were determined (Table 2).

TABLE 2. Descriptive statistics comparing the values obtained experimentally and simulated by the model for cloacal temperature, feed conversion, and water consumption of broilers.

\begin{tabular}{ccccccccccccc}
\hline \multirow{2}{*}{ Indices } & \multicolumn{3}{c}{ Cloacal Temperature $\left({ }^{\mathbf{0}} \mathbf{C}\right)$} & \multicolumn{3}{c}{ Feed Conversion } & \multicolumn{3}{c}{ Water consumption $\left(\mathbf{m L ~ d a y ~}^{-1}\right)$} \\
\cline { 2 - 12 } & Min. & Mea. & Medi. & Max. & Min. & Mea. & Medi. & Max. & Min. & Mea. & Medi. & Max. \\
\hline $\begin{array}{c}\text { Mean } \\
\text { deviation }\end{array}$ & 0.00 & 0.13 & 0.07 & 0.81 & 0.00 & 0.07 & 0.05 & 0.34 & 0.00 & 2.24 & 1.20 & 11.52 \\
\hline $\begin{array}{c}\text { Standard } \\
\text { Deviation }\end{array}$ & 0.00 & 0.09 & 0.05 & 0.57 & 0.00 & 0.05 & 0.04 & 0.24 & 0.00 & 1.59 & 0.85 & 8.14 \\
\hline Error (\%) & 0.00 & 0.30 & 0.18 & 1.95 & 0.10 & 4.85 & 3.43 & 21.7 & 0.00 & 2.05 & 1.10 & 9.98 \\
\hline
\end{tabular}

Min. $=$ Minimum; Mea.$=$ Mean; Medi. $=$ Median; Max. $=$ Maximum.

The ANN trained in this work for prediction of $t_{\text {clo }}$ presented an average deviation of $0.13^{\circ} \mathrm{C}$ (Table 2) that is, close to the value obtained by Ferreira et al. (2010). In this work, the authors developed a neuro-fuzzy model to predict the $t_{c l o}$ of broilers as a function of $\mathrm{RH}, \mathrm{t}_{\mathrm{db}}$, and air velocity, and the compared results between the neuro-fuzzy network and those experimentally measured obtained a mean deviation of $0.11^{\circ} \mathrm{C}$.

The mean percentage error found between the simulated and observed values of FC was $4.85 \%$. In turn, Schiassi et al. (2015) obtained an average percentage error of $1.94 \%$ for FC. It is noteworthy that while in this study the data were evaluated daily, in work developed by Schiassi et al.
(2015) the analyses were weekly; this study is characterized by lower variation resulting in lower error values.

When using ANN to predict the body mass of broilers, Ferraz et al. (2014) found mean values for absolute deviation, standard deviation, and percentage error of 3.3, 2.3 , and $1.2 \%$, respectively. For the ANN developed, considering the same statistical analyses, it can be verified that the values are modified according to the output variable; however, the mean values found in this study were close to the values published by the cited authors.

Vieira et al. (2011) developed an ANN to predict pre-slaughter losses through the mortality of broilers, and the results were not satisfactory due to low accuracy. Table 
3 shows that the MSEs have variation between output neurons; this reflects the actual behavior of the variable $\left(\mathrm{t}_{\text {clo, }}\right.$, $\mathrm{FC}$, and $\mathrm{C}_{\text {water }}$ ) instead of the absence of information. Also, when adjusting the linear regression models to confer the accuracy of an ANN developed with the observed values, it can be observed that the slope values closer to 1 indicate a better accuracy in the model (Tedeschi, 2006).
The values of the standard error and mean quadratic error associated with $\mathrm{C}_{\text {water }}$ are 3.29 and $3.40 \%$, respectively (Table 3). These values were higher than those of the other variables studied, and were influenced by oscillation in daily consumption that was influenced by factors such as age, rise in room temperature, and feed consumption (Gama et al., 2008).

TABLE 3. Standard error, square root of the mean square error (RMSE), regression coefficient, and intercept for cloacal temperature $\left(\mathrm{t}_{\mathrm{clo}}\right)$, feed conversion $(\mathrm{FC})$ and water consumption $\left(\mathrm{C}_{\mathrm{water}}\right)$ obtained experimentally and simulated by the model.

\begin{tabular}{cccc}
\hline Variable & Standard Error & RMSE & Regression Coefficients \\
\hline Cloacal Temperature & 0.17 & 0.19 & $0.8431 \pm 0.0379^{(1)}$ \\
Feed Conversion & 0.09 & 0.10 & $0.8683 \pm 0.0517^{(1)}$ \\
Water Consumption & 3.29 & 3.40 & $0.9648 \pm 0.0176^{(1)}$ \\
\hline
\end{tabular}

${ }^{(1)}$ The coefficients are significant according to the $\mathrm{t}$-test $(\mathrm{p}<0.05)$. All regressions were significant according to the $\mathrm{F}$-test $(\mathrm{p}<0.05)$.

A

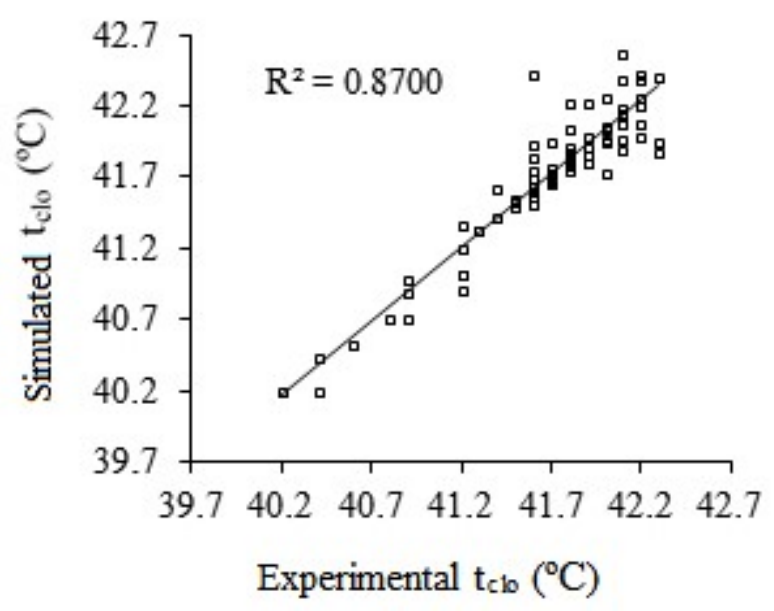

B.

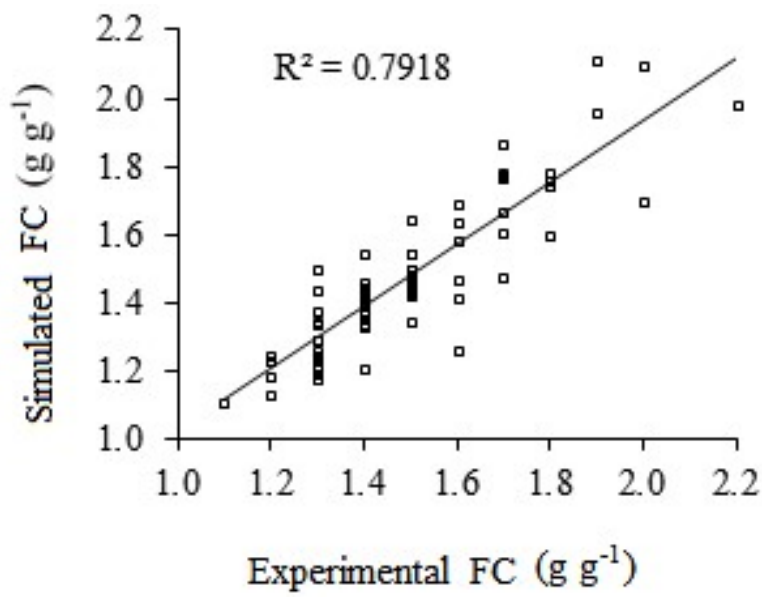

C.

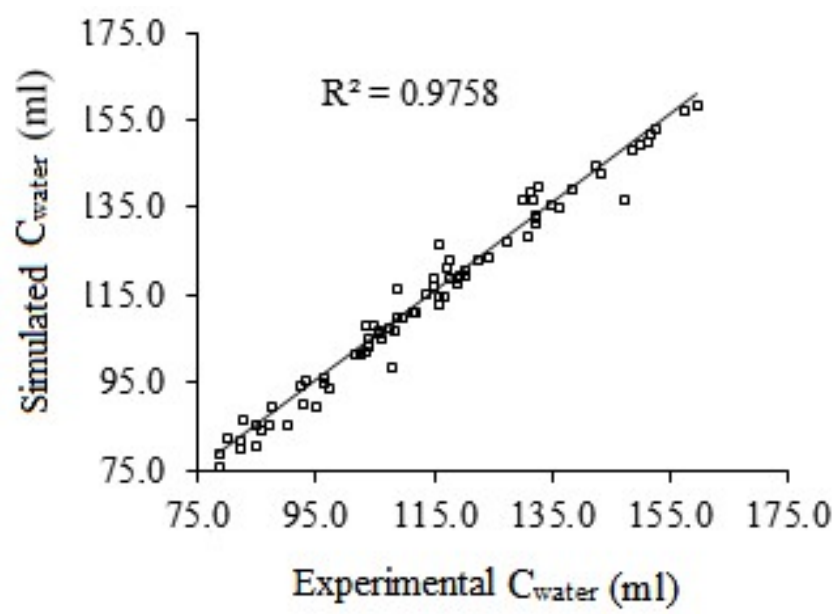

FIGURE 2. Linear regressions of cloacal temperature $\left(t_{\text {clo }}-A\right)$, feed conversion $(F C-B)$, and water consumption $\left(\mathrm{C}_{\text {water }}-C\right)$ of broilers obtained experimentally and simulated by the ANN model, in the second week of life.

Simple linear regressions of the values obtained experimentally and simulated by $\mathrm{ANN}$ are illustrated in Figure 2 , in which the values of $\mathrm{R}^{2}$ for $\mathrm{t}_{\mathrm{clo}}, \mathrm{FC}$, and $\mathrm{C}_{\mathrm{water}}$ were $0.87,0.79$, and 0.97 , respectively.

According to the mentioned results, the ANN with the best architecture performed well, because $87 \%$ of the predicted values for the $t_{\text {clo }}$ were achieved with absolute deviations ranging from 0 to 0.8 . For the case of $\mathrm{FC}$, the
ANN obtained satisfactory performance, because $79 \%$ of the predicted values were reached with absolute deviations ranging from 0 to 0.34 . For $C_{w a t e r}$, the performance was higher than the others, and $97 \%$ of the predicted values for the variable were reached with absolute minimum deviations of zero (0) and maximum sums of 1.20.

Therefore, choosing an architecture with the lowest EQM and with the highest $\mathrm{R}^{2}$ indicates that the predicted 
values will have the best results and, consequently, a better performing system for management aid in the second week of the production cycle.

According to the data obtained from the literature, Medeiros et al. (2001) developed an empirical model to predict FC and found a coefficient of determination $\left(\mathrm{R}^{2}\right)$ of 0.72 for the same variable under study; the $\mathrm{R}^{2}$ for the adjusted model in this study was 0.79 .

\section{CONCLUSIONS}

The methodology used in this work allowed us to obtain different models based on ANN. Thus, it can be verified that the application of repetitions (in this case, 10) for each number of neurons in the hidden layer (from 1 to 300), made it possible to obtain different random combinations of the training, validation, and testing data, allowing the ANN architectures to capture an appropriate combination for predicting output variables.

Thus, the proposed multilayer perceptron artificial neural network obtained adequate performance for the prediction of cloacal temperature, feed conversion, and water consumption of Cobb $500^{\circledR}$ strain broilers subjected to thermal challenges in the second week of the production cycle.

\section{ACKNOWLEDGMENTS}

The present work was carried out with the finacial support of the Coordenação de Aperfeiçoamento de Pessoal de Nivel Superior, Brasil (CAPES)_Funding Code 001of the Conselho Nacional de Desenvolvimento Cientifico e Tecnológico (CNPq) (Process 307746/2014-3) and Fundação de Amparo à Pesquisa do Estado de Minas Gerais (FAPEMIG).

\section{REFERENCES}

Al-Zghoul MB, Dalab AES, Yahya IE, Althnaian TA, Alramadan SY, Ali AM, Albokhadaim IF, El-Bahr SM, AlBusadah KA, Hannon KM (2015) Thermal manipulation during broiler chicken embryogenesis: Effect on mRNA expressions of Hsp108, Hsp70, Hsp47 and Hsf-3 during subsequent post-hatch thermal challenge. Research in veterinary science 103:211-217. DOI: https://doi.org/10.1016/j.rvsc.2015.10.015

Barbosa AH, Freitas MSR, Neves FA (2005)

Confiabilidade estrutural utilizando o método de Monte Carlo e redes neurais. REM: Revista Escola de Minas 58(3):247-255. DOI:

https://doi.org/10.1590/S0370-44672005000300011

Binoti DHB, Silva MLBM, Leite HG (2013) Redução dos custos em inventário de povoamentos equiâneos. Revista Brasileira de Ciências Agrárias 8(1):125-129. DOI: https://doi.org/10.5039/agraria.v8i1a2209

Boiago MM, Borba H, Souza PA, Scatolini AM, Ferrari FB, Giampietro-Ganeco A (2013) Desempenho de frangos de corte alimentados com dietas contendo diferentes fontes de selênio, zinco e manganês, criados sob condições de estresse térmico. Arquivo Brasileiro de Medicina Veterinária e Zootecnia 65(1):241-247.
Borges PH, Mendoza ZMSH, Maia JCS, Bianchini A, Fernándes HC (2017) Estimation of fuel consumption in agricultural mechanized operations using artificial neural networks. Engenharia Agrícola 37(1):136-147. DOI: http://dx.doi.org/10.1590/1809-4430-

Eng.Agric.v37n1p136-147/2017

Borges PH, Mendoza ZM, Morais PH, Santos RLD (2018) Artificial neural networks for predicting animal thermal comfort. Engenharia Agrícola 38(6):844-856. DOI: http://dx.doi.org/10.1590/1809-4430Eng.Agric.v38n6p844-856/2018

Brown-Brandl TM, Jones DD, Woldt WE (2005) Evaluating modelling techniques for cattle heat stress prediction. Biosystems Engineering 91(4):513-524. DOI: https://doi.org/10.1016/j.biosystemseng.2005.04.003

Cândido MG, Tinôco IFF, Pinto FAC, Santos NT, Roberti RP (2016) Determination of thermal comfort zone for early-stage broilers. Engenharia Agrícola 36(5):760-767. DOI: http://dx.doi.org/10.1590/1809-4430-

Eng.Agric.v36n5p760-767/2016

Cassuce DC, Tinôco IDF, Baêta FC, Zolnier S, Cecon PR, Vieira MDF (2013) Thermal comfort temperature update for broiler chickens up to 21 days of age. Engenharia Agrícola 33(1):28-36. DOI:

http://dx.doi.org/10.1590/S0100-69162013000100004

Castilho VAR, Garcia RG, Lima NDS, Nunes KC, Caldara FR, Nääs IA, Barreto B, Jacob FG (2015) Bem-estar de galinhas poedeiras em diferentes densidades de alojamento. Revista Brasileira de Engenharia de Biossistemas 9(2):122-131. DOI: http://dx.doi.org/10.18011/bioeng2015v9n2

Cobb (2013) Broiler Management Guide. Cobb-Vantress, $73 \mathrm{p}$.

Curtis SE (1983) Environmental management in animal agriculture. Ames, The Iowa State University, 410p.

Ferraz PFP, Yanagi Junior T, Yamid FHJ Castro JDO, Gates RS, Reis GM, Campos AT (2014) Predicting chick body mass by artificial intelligence-based models. Pesquisa Agropecuária Brasileira 49(7):559-568. DOI: http://dx.doi.org/10.1590/S0100-204X2014000700009

Ferraz PFP, Yanagi Junior T, Lima RRD, Ferraz GA, Xin $H$ (2017) Performance of chicks subjected to thermal challenge. Pesquisa Agropecuária Brasileira 52(2):113120. DOI: http://dx.doi.org/10.1590/s0100204x2017000200005

Ferraz PF, Yanagi Junior T, Hernandez-Julio YF, Ferraz GA, Silva MA, Damasceno FA (2018) Genetic fuzzy system for prediction of respiratory rate of chicks subject to thermal challenges. Revista Brasileira de Engenharia Agrícola e Ambiental 22(6):412-417. DOI: http://dx.doi.org/10.1590/1807-1929/agriambi.v22n6p412-417

Felix EF, Carrazedo R, Possan E (2017) Análise paramétrica da carbonatação em estruturas de concreto armado via Redes Neurais Artificiais. Revista ALCONPAT 7(3):302-316. DOI: http://dx.doi.org/10.21041/ra.v7i3.245 
Ferreira RP, Sassi RJ, Affonso CO (2011) Aplicação de uma rede neuro Fuzzy para a previsão do comportamento do tráfego veicular urbano na região metropolitana da cidade de São Paulo. Exacta 9(3):363-375.

Ferreira L, Junior TY, Lopes AZ, Lacerda WS (2010) Desenvolvimento de uma rede neuro-fuzzy para predição da temperatura retal de frangos de corte. Revista de Informática Teórica e Aplicada 17(2): 221-233.

Gama MNSQ, Togashi CK, Ferreira NT, Buim MR, Guastalli EL, Fiagá DAM (2008) Conhecendo a água utilizada para as aves de produção. Biológico 70(1):43-49.

Hernández-Julio YF, Yanagi Junior T, Pires FAM, Lopes AM, Lima RR (2014) Models for prediction of physiological responses of Holstein dairy cows. Applied Artificial Intelligence 28(8):766-792.

Kiran TR, Rajput SPS (2011) An effectiveness model for an indirect evaporative cooling (IEC) system: comparison of artificial neural networks (ANN), adaptive neuro-fuzzy inference system (ANFIS) and fuzzy inference system (FIS) approach. Applied Soft Computing 11(4):3525-3533. DOI: http://dx.doi.org/10.1016/j.asoc.2011.01.025

Klassen T, Martins TD, Cardozo Filho L, Silva EA (2009) Modelagem do sistema de resfriamento por imersão de carcaças de frangos utilizando redes neurais artificiais. Acta Scientiarum Technology 31(2):201-205.

Lima KAO, Garcia RG, Nääs IA, Caldara FR, Santana MR, Royer AFB, Barreto B, Castilho VAR (2014) Impacto da iluminação artificial no comportamento de frangos de corte. Agrarian 7(24):301-309.

Lopes JCO, Figueirêdo AVD, Lopes JB, Lima DCP, Ribeiro MN, Lima VBDS (2015) Zinc and vitamin E in diets for broilers reared under heat stress. Revista Brasileira de Saúde e Produção Animal 16(2):350-364.

MathWorks I (2013) Levenberg-Marquardt backpropagation. The MathWorks.

Matin H, Saki A, Aliarabi H, Shadmani M, Abyane HZ (2012) Intestinal broiler microflora estimation by artificial neural network. Neural Computing and Applications 21(5):1043-1047.

Mayes SL, Strawford ML, Noble SD, Classen HL, Crowe TG (2014) Cloacal and surface temperatures of tom turkeys exposed to different rearing temperature regimes during the first 12 weeks of growth. Poultry Science Association 94(6):1105-1114. DOI: http://dx.doi.org/10.3382/ps/peu058

Medeiros CM, Baêta FC, Oliveira RFM, Tinôco IFF, Albino LFT, Cecon PR (2001) Modelagem matemática das respostas de frango de corte, em função da temperatura, umidade e velocidade do ar. Engenharia na Agricultura 9(4):251-267.
Mirzaee-Ghaleh E, Omid M, Keyhani A, Dalvand MJ (2015) Comparison of fuzzy and on/off controllers for winter season indoor climate management in a model poultry house. Computers and Electronics in Agriculture 110:187-195. DOI:

https://doi.org/10.1016/j.compag.2014.11.017

Nascimento GR, Nääs IA, Baracho MS, Pereira DF, Neves DP (2014) Termografia infravermelho na estimativa de conforto térmico de frangos de corte. Revista Brasileira de Engenharia Agrícola e Ambiental 18(6):658-663.

Oliveira AA, Siqueira PH, Nisgoski S, Muniz, GBD, Ferreira JH (2015) Identificação de madeiras utilizando a espectrometria no infravermelho próximo e redes neurais artificiais. TEMA 16(2):81-95. DOI:

http://dx.doi.org/10.5540/tema.2015.016.02.0081

Pandorfi H, Almeida GLP, Guiselini C (2012) Zootecnia de precisão: princípios básicos e atualidades na suinocultura. Revista Brasileira de Saúde e Produção Animal 13(2):558-568.

Pandorfi H, Silva IJO, Sarnighausen VCR, Vieira FMC, Nascimento ST, Guiselini C (2011) Uso de redes neurais artificiais para predição de índices zootécnicos nas fases de gestão e maternidade na suinocultura. Revista Brasileira de Zootecnia 40(3):676-681.

Ribeiro R, Casanova D, Teixeira M, Wirth A, Gomes HM, Borges AP, Enembreck F (2019) Generating action plans for poultry management using artificial neural networks. Computers and Electronics in Agriculture 161:131-140. DOI: https://doi.org/10.1016/j.compag.2018.02.017

Rigo Júnior LO, Araújo JCS, Santos LN, Oliveira MLM (2016) Aplicação de Multi-Layer Perceptron para Previsão de Emissão de Gases derivados de Veículos a Diesel. Latin American Journal of Energy Research 3(2):1-11. DOI: http://dx.doi.org/10.21712/lajer.2016.v3.n2.p1-11

Rocha Neto OC, Teixeira ADS, Braga AP, Santos CC, Leão RA (2015) Application of artificial neural networks as an alternative to volumetric water balance in drip irrigation management in watermelon crop. Engenharia Agrícola 35(2):266-279. DOI:

http://dx.doi.org/10.1590/1809-4430-

Eng.Agric.v35n2p266-279/2015

Rostagno HS, Albino LFT, Donzele JL, Gomes PC, Oliveira RF, Lopes DC, Ferreira AS, Barreto SLT, Euclides RF (2011) Tabelas brasileiras para aves e suínos: composição de alimentos e exigências nutricionais. Viçosa, Universidade Federal de Viçosa, 3ed. 252p.

Santos DS, Arce AIC, Piza LV, Silva AS, Costa EJX, Tech ARB (2016) Redes bluetooth associadas a redes neurais artificiais para monitoramento de suínos. Archivos de zootecnia 65(252):557-563. DOI: https://doi.org/10.21071/az.v65i252.1926 
Schiassi L, Yanagi Junior T, Reis GM, Abreu LHP, Campos AT, Castro JO (2015) Modelagem fuzzy aplicada na avaliação do desempenho de frangos de corte. Revista Brasileira de Engenharia Agrícola e Ambiental 19(2):140146. DOI: http://dx.doi.org/10.1590/1807-

1929/agriambi.v19n2p140-146

Sousa FC, Tinôco IFF, Paula MO, Silva AL, Souza CF, Batista FJF, Barbari M (2016) Medidas para minimizar a emissão de amônia na produção de frangos de corte: revisão. Revista Brasileira de Engenharia de Biossistemas 10(1):51-61. DOI:

http://dx.doi.org/10.18011/bioeng2016v10n1p51-61

Tedeschi LO (2006) Assessment of the adequacy of mathematical models. Agricultural Systems 89(23):225-247. DOI:

http://dx.doi.org/10.1016/j.agsy.2005.11.004
Vieira FMC, Rodrigues VC, Silva IJO, Lombardi LO, Barbosa Filho JAD (2011) Simulação da mortalidade préabate de frangos de corte por meio das redes neurais artificiais. Thesis 16:56-64.

Yanagi Junior T, Schiassi L, Abreu LHP, Barbosa JA, Campos AT (2012) Procedimento fuzzy aplicado à avaliação da insalubridade em atividades agrícolas. Engenharia Agrícola 32(3):423-434. DOI: https://doi.org/10.1590/S0100-69162012000300002

Zhang SS, Su HG, Zhou Y, Li XM, Feng JH, Zhang MH (2016) Effects of sustained cold and heat stress on energy intake, growth and mitochondrial function of broiler chickens. Journal of Integrative Agriculture 15(10):23362342. DOI: http://dx.doi.org/10.1016/S20953119(15)61314-4 